\title{
Role of Ozone Therapy and Cancer: Myth or Reality?
}

\author{
Authors \\ Vatsal Singh $^{1}$, Rishabh Gupta $^{2}$, Sandeep Kumar $^{3}$, Bhaskar Agarwal $^{4 \#}$ \\ ${ }^{1,2}$ MBBS, King George's Medical University, Lucknow \\ ${ }^{3}$ Prof., MS, FRCS (Edinburgh), PhD (Wales), MMSc (Newcastle), Former Director, AIIMS Bhopal \\ ${ }^{4}$ MDS, Associate Professor, Department of Prosthodontics, King George's Medical University, Lucknow \\ ${ }^{\#}$ Corresponding Author \\ Dr Bhaskar Agarwal \\ H. No. 1060, Sadar Gola Bazar, Cantt., Lucknow-226002, Uttar Pradesh, India
}

\begin{abstract}
Aim: Our aim to establish whether or not ozone therapy has any role in cancer treatment.

Material \& Method: A thorough computer search using PubMed, Google Scholar, Wikipedia and Yahoo search engine, search through cross-references and hand search in the libraries was performed.

Results: The basis of using ozone for the treatment of cancer is that it reduces tumor hypoxemia, thus allowing greater efficacy of radiotherapy and/or chemotherapy, is indeed strong.

Conclusion: In spite of introduction of many new modern age drugs and advanced surgical procedures, there is no definite cure for disseminated cancer at present. Aggressive treatment options like radiotherapy and chemotherapy have many potentially fatal side effects and decrease quality of life of the patients. Ozone may be an additional option to improve patient related outcome and reduce side effects.

Keywords: Ozone therapy, Cancer, Radiotherapy, Chemotherapy.
\end{abstract}

\section{Introduction}

Ozone is a naturally occurring allotrope of oxygen. Medical interest in ozone has been there over several decades. Of late a few claims especially in the lay press have been published for using ozone in medical conditions like backache, ischemic syndromes, dental caries and cancer. There is however no hard-core scientific data published on the efficacy of ozone in medical practice. In this review article we have attempted to update the information on ozone treatment in cancer in general. A thorough computer search using PubMed, Google Scholar, Wikipedia and Yahoo search engine, search through crossreferences and hand search in the libraries was performed. There were a total of 98 articles identified on various medical uses and effects of ozone. There were total 18 articles on ozone as related to cancer. Of these, most were just rhetoric or unsystematic reviews. These papers in general described how lack of oxygen or ischemia has a potential adverse outcome and theoretical use of ozone to draw benefit from treatment. There were only 4 published articles (1 laboratory study and 3 case series trials in human subjects) on ozone as directly applied as an additional agent in cancer treatment. In order to minimize the bias in reviewing, a tabular form of summary of the clinical studies both case series and trials have also been provided. 
Available literature on history of ozone treatment in various medical indications, its chemistry and molecular physics, biological basis of action especially in cancer and its clinical and experimental evidence of its efficacy has been reviewed. Ozone is created in the stratosphere, 20$30 \mathrm{~km}$ above the sea level. When strong UV radiations (photons less than $320 \mathrm{~nm}$ ) collide with the oxygen in stratosphere; photons transfer their energy to convert oxygen into ozone ${ }^{1}$. The ozone thus produced filters harmful UV rays and therefore has a protective role in earth's ecological harmony. In 1840, Christian Friedrich Schonbein, used electric sparks in a closed air chamber to produce a pale blue gas with a distinct odor and identified it as ozone ${ }^{2}$. First therapeutic use of ozone can be traced back to 1870 when C. Lender used it to purify blood in test tubes ${ }^{3}$. Since then prospect of ozone therapy in many diseases has been explored. As early as the First World War, ozone's anti-microbial properties were employed to treat wounds and burns. A major revolution in ozone therapy came with the advent of $21^{\text {st }}$ century, when highly specialized ozonators were built that could produce precise and purest mixture of oxygen and ozone. A critical advancement towards effective ozone therapy has been the identification of inert elements to withstand ozone's oxidative properties ${ }^{3}$. The list of substances that are inert to ozone include teflon, kynar(polyvinyl fluoride), silicone and gold. At present, anti-microbial, anti-oxidant, enhancement of blood flow and immunomodulatory effects of ozone have been demonstrated. Over 200 diseases have been claimed to be treated or subdued using ozone therapy. One major application is in the field of cancer treatment. In spite of introduction of many new modern age drugs and advanced surgical procedures, there is no definite cure for disseminated cancer at present. Aggressive treatment options like radiotherapy and chemotherapy have many potentially fatal side effects and decrease quality of life of the patients.
Ozone may be an additional option to improve patient related outcome and reduce side effects.

\section{Role of Hypoxia in tumors}

A tumor is an abnormal mass of tissue, the growth of which exceeds and is uncoordinated with that of the normal tissues and persists in the same excessive manner after cessation of the stimuli which evoked the change. The tumor grows rapidly but it cannot enlarge beyond 1-2 $\mathrm{mm}$ in size unless it is vascularized ${ }^{4}$. For acquiring additional nutrition required for their growth, tumor cells stimulate the host cells to form new blood vessels, i.e., angiogenesis by secretion of Vascular Endothelial Growth Factor (VEGF). Neovascularization not only promotes tumor growth but also helps in metastasis of tumor as the newly formed blood vessels are leaky and the tumor cells can access them to reach distant sites. The first clinical evidence that the metastasis is angiogenesis dependent was demonstrated by the group of Hughes, Woodock and Srivastava ${ }^{5}$ in skin melanomas. The endothelial cells of new blood vessels stimulate growth of adjacent tumor cells by secreting Insulin-like GFs and PDGF ${ }^{6}$. However, tumor blood vessels differ from the normal vasculature by being tortuous and irregularly shaped and by being leaky. Tumor blood vessels neither contain smooth muscle cells nor do they have any autonomic nerve supply ${ }^{7}$. Even in presence of ongoing neovascularisation, tumor contains areas of hypoxia ${ }^{8}$. In 1931, Dr. Otto Warburg was awarded the Nobel Prize in physiology for his work on "mode of action of respiratory enzyme in tumor cells" $"$. He concluded that the prime cause of all malignant growth is oxygen deprivation which leads to anaerobic respiration (glycolysis) in malignant cells. The genesis of hypoxia in tumors can be explained by:-

(i) Increased distance between the cells to be perfused and the capillaries: It has been observed that the tumor vascular growth is chaotic and haphazard, resulting in varying distance between the capillaries and cells in some parts of tumor. 
The diffusion distance between cells and capillaries is critical, such that oxygen cannot reach cells farther away than 100-150 microns from the capillaries. This is the main reason for hypoxic regions within a solid tumor. One study on fibrosarcomas and mammary carcinoma concluded poor tissue perfusion in the cancer cells to be the cause of hypoxia. The intravascular oxyhemoglobin saturation decreased going from the surface to the centre of the tumor ${ }^{10}$.

(ii) Induction of thrombophilic state: Another study states that cancer cells secrete procoagulant and tissue factor, bringing about hypercoaguable and thrombophilic state which can cause hypoxia ${ }^{11}$. Hypoxia further worsens this state by inducing E-selectins and adhesions molecules on the endothelial cells ${ }^{12}$.

(iii) High rate of division: Another factor attributing to hypoxic state can be high rate of division and increased oxygen consumption by cancer cells.

The buildup of hypoxia in cancer cells provides favorable milieu for tumor cell growth. It has been shown in breast cancer cells, that hypoxia favors synthesis of metalloproteases which cleave typeIV collagen, thereby helping in metastasis ${ }^{13}$. Hypoxia also stabilizes transcription factor HIF1(Hypoxia-Inducible Factor) which on binding to hypoxia responsive element produces VEGF, again an angiogenic factor ${ }^{14}$. TNF- $\alpha$, a cytokine and its soluble receptors produced by epithelial tumor cells and macrophages, are both enhanced in hypoxic conditions ${ }^{15}$.

In accordance with Dr. Otto Warburg, several studies supporting harmful role of hypoxia and the underlying pathogenesis have been reported. Thus, ameliorating local tumor hypoxia can prove to be a major interventional modality in the course of cancer treatment. In this context, ozone therapy opens new windows towards cure of cancer.

\section{Basis of Ozone therapy in Cancer}

The first use of ozone in cancer treatment dates back to 1951, when Dr. William Turska pioneered the method of injecting ozone into rectal veins of his patients to reach the liver via portal circulation. He tried these techniques in patients of many liver diseases including liver cancer, although the complete details of his trials and the obtained results are not available to derive any inference. In recent years, apart from antimicrobial effects, application of ozone in cancer therapy as well as other diseases as complementary medicine has been realized.

\section{(i) Hypoxia Abatement:}

High oxygenation potential property of ozone is the basis of its usefulness against cancer. It enhances tumor cells oxygenation in multiple ways:-

(a) Enhancing oxygen saturation of blood: Ozone increases oxygen saturation of hemoglobin and shifts the oxygen-saturation curve towards the right side, so that more oxygen is released to peripheral tissues. Experiments prove that autohemotherapy increases 2,3bisphosphoglycerate in $\mathrm{RBCs}^{16}$. There is no danger of embolism with ozone in blood as it is highly soluble ${ }^{17}$. Also, no adverse changes in RBC intergrity ${ }^{18}$ or in neutrophil functions ${ }^{19}$ have been found using autohemotherpay. All the above findings ensure complete safety of autohemotherapy.

(b) Vasodilatory Effect: Ozone also enhances blood supply to peripheral tissues by vasodilatory effect. This property can be attributed to its stimulatory effect on vasodilators like NO. A study on cerebral blood flow including 7 subjects, showed $75 \%$ enhancement in carotid artery blood flow with 3 sessions of ozone autohemotherapy over a period of only one week ${ }^{20}$.

(c) Reducing Blood Viscosity: Ozone autohemotherapy decreases blood viscosity. This was demonstrated in a study on 27 patients with peripheral occlusive arterial diseases, where autohemoperfusion for 30 minutes significantly decreased blood viscosity and fibrinogen levels ${ }^{21}$. Thus, in the following ways local tumor tissue oxygenation is raised. More hypoxic the tumour tissue is, more is the change in local $\mathrm{PO}_{2}{ }^{22}$. 
(ii) Immunomodulation and Anti-oxidant Agent:

There are other properties of ozone which make it an effective tool in combating cancer. It is a potent immunomodulator and antioxidant. Preconditioning with ozone at low concentrations exerts inhibitory effects on TNF- $\alpha$ production and on the other hand it exerts influence on the antioxidant prooxidant balance for preservation of cell redox state by the increase of endogenous anti-oxidant systems ${ }^{23}$. Anti oxidant effect of ozone is also seen when continuous exposure to low concentration of ozone (at $0.2 \mathrm{ppm}$ ) increases Glutathione (GSH) peroxidase levels in cells ${ }^{24}$.

(iii) Anti-Inflammatory Agent:

Chronic inflammation induced by biological, chemical and physical factors has been associated with increased risk of human cancers at different sites $^{25}$. Aqueous ozone has also been demonstrated to inhibit inflammatory cytokines like NF- $\kappa \mathrm{B}$ system, involved in progression of normal cells to malignancy ${ }^{26}$.

\section{Clinical Evidence of Ozone Therapy in Cancer Patients}

Ozone improves the prognosis in cancer patients by acting synergistically with the present treatment modalities. A very significant research study evaluating the selective efficacy of ozone against human cancer cells was published in 1980 . $0.3-0.5 \mathrm{ppm}$ of ozone was successful in inhibiting $40-60 \%$ of cancer cells (lung, breast and uterine cancer cells) and $0.8 \mathrm{ppm}$ ozone inhibited $90 \%$ of the cancer cells. While $0.3-0.5 \mathrm{ppm}$ ozone had no adverse effects on normal control cells, $0.8 \mathrm{ppm}$ ozone was toxic to less than half of the control cells $^{27}$. However, the study was laboratory based and could not establish clinical evidence. In Leukemia, adjuvant ozone therapy in synergism with other drugs has even induced differentiation, apoptosis and necrosis of malignant cells ${ }^{28}$. The sensitivity of tumor cells to radiotherapy has been shown to be about three times as great when irradiated in a well oxygenated medium as under anoxic condition $^{29}$. Another similar study on R1H
Rhabdomyosarcoma of rats reported that in contrast to primary tumors, tumor recurrences had lower oxygenation and responded poorly on irradiation $^{30}$.

A few direct clinical human trials have further consolidated role of ozone as an adjuvant therapy in cancer treatment. In a study by $\mathrm{Clavo}^{31}$, mean survival of 19 patients suffering from advanced head and neck tumors, undergoing radiotherapy was found to increase when they received adjuvant systemic ozone therapy in comparison to adjuvant chemotherapy ${ }^{31}$. However, the number of patients included in the study was small. In patients of multiple myeloma, bisphosphonates are universally prescribed. In recent years a major side effect of bisphosphonates in the form of "Osteonecrosis of Jaw" has been increasingly documented. In a clinical trial, osteonecrosis in patients of multiple myeloma was treated by daily ozone therapy for 14 days along with antibiotics, and surgical curettage at the $7^{\text {th }}$ day. 11 out of 12 patients were completely relieved of their symptoms of pain, secretion and halitosis ${ }^{32}$.

Ozone's effectiveness in cancer may not be as straight forward as it seems, and will inevitably depend upon the clinical setting. The results are ought to vary with the clinician's skills, sophistication of instruments and the perspective of interpretation. As at present, direct clinical studies supporting effectiveness of ozone in cancer treatment are limited, there is a strong need of further unbiased clinical trials. Some of the important clinical trials on humans assessing efficacy of ozone therapy against cancer are summarized in Table 1. 
Table 1: Summary of studies on ozone usage in the treatment of solid tumors

\begin{tabular}{|c|c|c|c|c|}
\hline SN & References & Objective & Study design & Result \\
\hline 1. & $\begin{array}{l}\text { F Sweet, MS Kao, } \\
\text { SC Lee, WL } \\
\text { Hagar, and WE } \\
\text { Sweet, } 1980^{27}\end{array}$ & $\begin{array}{l}\text { To assess } \\
\text { selective effect of } \\
\text { ozone on growth } \\
\text { of Human cancer } \\
\text { cells. }\end{array}$ & $\begin{array}{l}\text { Laboratory trial on cultured } \\
\text { tumor cells: } \\
\text { Separate cultures of lung, breast } \\
\text { and uterine cancer cells and } \\
\text { control culture of non-cancerous } \\
\text { human lung diploid fibroblasts } \\
\text { over a period of } 8 \text { days, exposed } \\
\text { to dose dependent ozone }(0.3- \\
0.8 \mathrm{ppm}) \text {. }\end{array}$ & $\begin{array}{l}0.3-0.5 \mathrm{ppm} \text { of ozone was successful in } \\
\text { inhibiting } 40-60 \% \text { of cancer cells and } \\
0.8 \mathrm{ppm} \text { ozone inhibited } 90 \% \text { of the cancer } \\
\text { cells. While } 0.3-0.5 \mathrm{ppm} \text { ozone had no } \\
\text { adverse effects on normal control cells, } \\
0.8 \mathrm{ppm} \text { ozone was toxic to less than half of } \\
\text { the control cells. } \\
\text { Author's conclusion: Laboratory based study } \\
\text { of efficacy of ozone shown. No clinical data } \\
\text { to show its effect in human tumors in vitro or } \\
\text { in vivo. }\end{array}$ \\
\hline 2. & $\begin{array}{l}\text { Clavo B, Pérez JL, } \\
\text { López L, Suárez } \\
\text { G, Lloret M, } \\
\text { Rodríguez V, } \\
\text { Macías D, Santana } \\
\text { M, Hernández M, } \\
\text { Martín-Oliva R, } \\
\text { Robaina F, 2004 }\end{array}$ & $\begin{array}{l}\text { To assess the } \\
\text { effect of ozone } \\
\text { therapy on tumor } \\
\text { oxygenation. } \\
\text { Tacit hypothesis: } \\
\text { Poorly } \\
\text { oxygenated } \\
\text { tumor cell if } \\
\text { made better } \\
\text { oxygenated, it } \\
\text { will be more } \\
\text { treatable by } \\
\text { chemotherapy } \\
\text { and radiotherapy. }\end{array}$ & $\begin{array}{l}\text { Clinical trial: } \\
\text { Elective autohemotransfusion } \\
\text { (addition of } 200 \mathrm{ml} \mathrm{O}_{2}-\mathrm{O}_{3} \text { mix. } \\
\text { at } 60 \text { gammas conc. to } 200 \mathrm{ml} \\
\text { of extracted venous blood and } \\
\text { then retransfusion) performed } \\
\text { on } 18 \text { patients }(3 \text { session over } 1 \\
\text { week) with accessible tumors of } \\
\text { head and neck region(14), } \\
\text { gynaecological tumors }(2) \text { and } \\
\text { bone metastasis in chest wall }(2) \text {. } \\
\text { Oxygenation levels were } \\
\text { measured with polarographic } \\
\text { needle probes. }\end{array}$ & $\begin{array}{l}\text { Significant decrease in hypoxic values of } \leq \\
10 \text { and } \leq 5 \mathrm{mmHg} \text { of } \mathrm{pO}_{2} \text {. When } \\
\text { individually assessed, a significant and } \\
\text { inverse non-linear correlation was observed } \\
\text { between increase in oxygenation and the } \\
\text { initial tumor } \mathrm{pO}_{2} \text { values, thus indicating that } \\
\text { the more poorly-oxygenated tumors } \\
\text { benefited most. } \\
\text { Author's conclusion: The study provides } \\
\text { indirect evidence of effectiveness of ozone } \\
\text { in cancer treatment. } 18 \text { patients were } \\
\text { included in this trial without a control group } \\
\text {-a surrogate outcome of cancer treatment in } \\
\text { improved oxygenation of tumor was used. }\end{array}$ \\
\hline 3. & $\begin{array}{l}\text { Clavo B, Ana R, } \\
\text { Marta L, Laura L, } \\
\text { Gerardo S, David } \\
\text { M, Victor R, } \\
\text { Maria } \\
\text { Roberto AH, } \\
\text { Santiago Q, José } \\
\text { MC, Francisco R, } \\
2004^{31}\end{array}$ & $\begin{array}{l}\text { To evaluate the } \\
\text { clinical effect of } \\
\text { Ozone therapy in } \\
\text { patients with } \\
\text { advanced H\&N } \\
\text { cancer in the } \\
\text { course of their } \\
\text { scheduled } \\
\text { radiotherapy. }\end{array}$ & $\begin{array}{l}\text { Randomized clinical trial: Over } \\
\text { a period of } 3 \text { yrs, } 19 \text { patients of } \\
\text { advanced head and neck tumor } \\
\text { undergoing radiotherapy were } \\
\text { recruited and divided into two } \\
\text { groups. First group ( } 12 \text { patients, } \\
\text { mean age }=54 \text { yrs) was treated } \\
\text { with adjuvant chemotherapy } \\
\text { while the second group ( } \\
\text { patients, mean age=64 yrs) was } \\
\text { treated with adjuvant systemic } \\
\text { ozone therapy twice weekly } \\
\left(200 \text { ml } \mathrm{O}_{2}-\mathrm{O}_{3} \text { mix. at } 60\right. \\
\text { gammas). }\end{array}$ & $\begin{array}{l}\text { The mean survival duration of second group } \\
\text { (older patients, } 71 \% \text { lymph node } \\
\text { involvement) was } 8 \text { months while the mean } \\
\text { survival duration of first group (younger } \\
\text { patients, } 8 \% \text { lymph node involvement) was } 6 \\
\text { months. } \\
\text { Author's conclusion: Number of patients } \\
\text { included was small, no adverse effect } \\
\text { reported, evidence of efficacy is small. } \\
\text { Further trials necessary. }\end{array}$ \\
\hline 4. & $\begin{array}{l}\text { Maria Teresa } \\
\text { Petrucci, Cristiano } \\
\text { Gallucci, } \\
\text { Alessandro } \\
\text { Agrillo, Maria } \\
\text { Cristina Mustazza, } \\
\text { Robin Fo, } 2007^{32}\end{array}$ & $\begin{array}{l}\text { To assess role of } \\
\text { ozone therapy in } \\
\text { the treatment of } \\
\text { osteonecrosis of } \\
\text { the jaws in } \\
\text { multiple } \\
\text { myeloma } \\
\text { patients. }\end{array}$ & $\begin{array}{l}\text { Clinical trial: } \\
12 \text { patients of multiple myeloma } \\
\text { with osteonecrosis of jaw(ONJ) } \\
\text { were recruited. Bisphosphonates } \\
\text { were discontinued. Along with } \\
\text { surgical curettage adjuvant } \\
\text { ozonetherapy and antibiotic } \\
\text { therapy were given for } 14 \text { days. }\end{array}$ & $\begin{array}{l}\text { Eight patients (75\%) achieved complete } \\
\text { responses (resolution of ONJ) and four } \\
(25 \%) \text { achieved partial responses } \\
\text { (improvement with persistence of lesion). In } \\
\text { all patients, pain, secretions and halitosis } \\
\text { were overcome. Partial responders had a } \\
\text { longer history of disease and more previous } \\
\text { cycles of bisphosphonate therapy. } \\
\text { Author's conclusion: The therapy was aimed } \\
\text { at treating the common side-effect of ONJ } \\
\text { during treatment of head and neck tumors } \\
\text { and not directly the tumor itself. Among all } \\
\text { the } 3 \text { treatments, role of ozone could not be } \\
\text { ascertained. }\end{array}$ \\
\hline
\end{tabular}




\section{Conclusion}

Ozone, an allotrope of oxygen, was discovered in 1840. Its industrial production started at the turn of the century. Its medical usage is accorded on account of increasing local or systemic oxygenation. Use in clinical medicine has been envisaged as antiseptic, antimicrobial, immunomodulatory and potentiating cancer treatments by enhancing blood circulation and oxygen saturation. The prime advantage with ozone is diffuse action all over the body. According to required area of application, it can be used in several forms like aqueous ozone, ozonated oils or as insufflations. Only 4 clinical studies could be found on direct use of ozone in solid tumors in the last 30 years. The basis of using ozone for the treatment of cancer that it reduces tumor hypoxemia, thus allowing greater efficacy of radiotherapy and/or chemotherapy, is indeed strong. There is paucity of experimental and clinical data. The experimental and clinical data summarized in Table 1 is insufficient to conclude that ozone is effective in the treatment of solid tumors as adjuvant modality. However, there is sufficient data to suggest that properly designed studies to test the efficacy of ozone in cancer should be conducted. Furthermore, phase 1 and 2 studies on its dosage, toxicity, routes and modes of administration also need to be done with better intensity.

\section{References}

1. Brewer AW, Wilson AW: The regions of formation of atmospheric ozone. $Q J R$ Meteorol Soc 1968, 94(401):249-65.

2. Schönbein CF: On the Odour Accompanying Electricity and on the Probability of its Dependence on the Presence of a New Substance. Philosophical Magazine 1840, 17:293-94.

3. Seidler V, Linetskiy I, Hubálková H, Sta? ková H, Šmucler R, Mazánek J: Ozone and Its Usage in General Medicine and Dentistry: A Review article. Prague Medical Report 2008, 109(1):5-13.
4. Folkman J: Role of angiogenesis in tumor growth and metastasis. Semin Oncol 2002, 29:15-18.

5. Srivastava A, Hughes LE, Woodock JP, and Laidler P: Vascularity in cutaneous melanoma detected by Doppler sonography and histology; correlation with tumor behavior. $B r \quad J$ Cancer 1989, 59(1):89-91.

6. Carmeliet P: Angiogenesis in health and disease. Nat Med 2003, 9:653.

7. Jain RK: Haemodynamic and transport barriers to the treatment of solid tumours. Int J Radiat Biol 1991, 60(1-2):85-100.

8. Williams KJ, Cowen RL, Stratford IJ: Hypoxia and oxidative stress. Tumour hypoxia - therapeutic considerations. Breast Cancer Res 2001, 3(5):328-31.

9. Warburg O: The Prime Cause and Prevention of Cancer, Lecture delivered to Nobel Laureates on June 30, 1966.

10. Fenton BM, Lord EM, Paoni SF: Intravascular HBO saturations, perfusion and

hypoxia in spontaneous and transplanted tumor models. Int $J$ Cancer 2001, 93(5):693-98.

11. Gouin-Thibault I, Achkar A, Samama MM: The thrombophilic state in cancer patients.

Acta Haematol 2001, 106(1-2):33-42.

12. Zund G, Nelson DP, Neufeldt EJ, Dzus AL, Bischoffii J, John E. Mayer, and Colgan S: Hypoxia enhances stimulusdependent induction of E-selectin on aortic endothelial cells. Proc. Natl. Acad. Sci 1996, 93:7075-80.

13. Canning MT, Postovit LM, Clarke SH, Graham CH.: Oxygen-mediated regulation of gelatinase and tissue inhibitor of metalloproteinases-1 expression by invasive cells. Exp Cell Res 2001, 267(1):88-94.

14. Ema M, Taya S, Yokotani N, Sogawa K, Matsuda Y, Fujii-Kuriyama Y: A novel b 
HLH-PAS factor with close sequence similarity to hypoxia-inducible factor 1alpha regulates the VEGF expression and is potentially involved in lung and vascular development. Proc Natl Acad Sci 1997, 94(9):4273-78.

15. Scannell G, Waxman K, Kaml GJ, Ioli G, Gatanaga T, Yamamoto R, Granger GA: Hypoxia induces a human macrophage cell line to release tumor necrosis factor-alpha and its soluble receptors in vitro. J Surg Res 1993, 54(4):281-85.

16. Viebahn-Hansler R. Einfluss auf den rythrozytenstoffwechsel. In: OzonHandbuch. Grundlagen- Prevention Therapie. Landsberg/Lech. Ecomed 1995, 1-15.

17. Rokitansky O: Klinik und biochemie der ozon therapy. Hospitals 1982, 52:643,711.

18. Zimran A, Wasser G, Forman L, Gelbart T, Beutler E: Effect of Ozone on Red Blood Cell Enzymes and Intermediates. Acta Haematol 1999, 102:148-51.

19. Margalit M, Attias E, Attias D, Elstein D, Zimran A, Matzner Y: Effect of ozone on neutrophil function in vitro. Int $J$ Lab Hematol 2001, 23(4):243-47.

20. Clavo B, Catalá L, Pérez J, Rodríguez V, Robaina F: Ozone Therapy on Cerebral Blood Flow: A Preliminary Report. Evid Based Complement Alternat Med 2004, 1(3):315-19.

21. Guinta R, Coppola A, Luongo C, Sammartino A, Guastafierro S, Grassia A, Giuyntao L, Plascolo L, Tirelli A, Coppola L: Ozonized autohemotherapy improves hemorheological parameters and oxygen delivery to tissues in patients with peripheral occlusive arterial diseases. Ann Hematol 2001, 80:745-48.

22. Clavo B, Pérez JL, López L, Suárez G, Lloret M, Rodríguez V, Macías D, Santana M, Hernández M, Martín-Oliva R, Robaina F: Ozone therapy for Tumor Oxygenation: A Pilot Study. Evid Based
Complement Alternat Med 2004, 1(1):9398.

23. Zamora ZB, Borrego A, Orlay YL, Ricardo Gonzalez, Menendez S, Hernandez F, Schulz S: Effects of Ozone Oxidative Preconditioning on TNF- $\alpha$ Release and Antioxidant-Prooxidant Intracellular Balance in Mice During Endotoxic Shock. Mediators Inflamm 2005, 24(1):16-22.

24. Chow CK, Dillard CJ, Tappel AL: Glutathione peroxidase system and lysozyme in rats exposed to ozone or nitrogen dioxide. Environmental Research 1974, 7(3):311-19.

25. Hiroshi O-T, Bakary SS, Tomohiro S: Prevention of human cancer by modulation of chronic inflammatory processes. Mutation Research/Fundamental and Molecular Mechanisms of Mutagenesis 2005, 591(1-2):110-22.

26. Huth KC, Saugel B, Jakob FM, Cappello C, Quirling M, Paschos E, Ern K, Hickel $\mathrm{K}$, Brand K: Effect of Aqueous Ozone on the NF- kB system. J Dent Res 2007, 86(5):451-56.

27. Sweet F, Kao MS, Lee SC, Hagar WL, Sweet WE: Ozone selectively inhibits growth of human cancer cells. Science 1980, 209:931-33.

28. Canadian patent: 2192602. [http://brevetspatents.ic.gc.ca/opic-

cipo/cpd/eng/patent/2192602/summary.ht ml?type=number_search]

29. Gray LH, Conger AD, Ebert M, Scott OC: The Concentration of Oxygen Dissolved in Tissues at the Time of Irradiation as a Factor in Radiotherapy. Br J Radiol 1953, 26(312):638-48.

30. Kehrl W, Sagowski C, Wenzel S, Zywietz $\mathrm{F}$ : Oxygenation of tumor recurrences following fractionated radiotherapy of primary tumors: Studies on the rhabdomyosarcoma $\mathrm{R} 1 \mathrm{H}$ of the rat. Strahlenther Onkol 2004, 180(6):383-90. 
31. Clavo B, Ana R, Marta L, Laura L, Gerardo S, David M, Victor R, Maria AH, Roberto M, Santiago Q, José MC, Francisco R: Adjuvant Ozonetherapy in Advanced Head and Neck Tumors: A Comparative Study. Evid Based Complement Alternat Med 2004, 1(3):32125.

32. Petrucci MT, Cristiano G, Alessandro A, Maria CM, Robin F: Role of ozone therapy in the treatment of osteonecrosis of the jaws in multiple myeloma patients. Haematol 2007, 92(9):1289-90. 